\title{
From Commentary to Philosophy, or Lectio and Disputatio in Indian Buddhist Commentarial Literature*
}

\author{
Vincent Eltschinger \\ École Pratique des Hautes Études (EPHE) \\ PSL University, Paris
}

As one of the editors of the present volume recently argued, "the problem of how to make sense of texts" is "the lowest common denominator of philological practice." 1 And indeed, "[i]f we were to redefine philology [...] we would think of it most simply as the discipline of making sense of texts." ${ }^{2}$ This is of course to say that interpretation has played a prominent role in the "reading practices" (Pollock 2015a: 12, 20) we are inclined to regard as cultural declensions of philology understood as a cross-cultural phenomenon calling for historical and comparative analysis. In this perspective, philological practices of the kind Pollock terms "hermeneutical philologies" (2015a: 14) can be expected to have even greater importance in cultures finding themselves in a "hermeneutic situation" (Bazán). ${ }^{3}$ This was obviously the case of western medieval Christianity and Indian Buddhism, where legal, moral and soteriological practice was largely dependent on the proper interpretation of a set of scriptures with varying degrees of authoritativeness. In the past decades, the scholarly and intellectual dispositifs of these two cultures have been referred to as "scholasticisms" with increasing frequency, scholasticism being characterized as a set of institution-based, self-conscious and highly sophisticated textual practices developed in order to study, appropriate, harmonize and often defend various types of auctoritates, and in which commentary played a central role in allowing for literal understanding, doctrinal amplification, and apologetics.

Close scrutiny of the theory and practice of commentary in Latin medieval Europe and Buddhist India reveals interesting structural and functional similarities. Late medieval commentaries and their Buddhist counterparts (at least as far as normative commentarial technique and theory are concerned) (1) consciously make room for debate and dialectics by comprising, generally towards the end of a commentarial sequence, a section devoted to dispelling doubts and responding to objections. (2) Many of these contradictions are explicitly said to be motivated by at least apparent contradictions - whether internal inconsistencies, conflict between authorities, or contradiction with reason(ing). (3) Features (1) and (2) can certainly be regarded as points of mere technical interest. However, these concluding sections played an important role in the development of philosophy itself in the two contexts. For whereas the disputatio is generally considered to have emancipated itself from the commentary (lectio) via the quaestio disputata, Buddhist philosophy as we know it from the works of Dignāga (around 500) and especially Dharmakīti (around 600) is structurally indebted to commentarial strategies formalized first in handbooks of exegetics composed slightly before and after $400 \mathrm{CE}$. Thus in addition to shedding comparative light on a particular aspect of commentarial technique, the present paper also attempts to follow one thread in the complex genealogy of philosophy in the Buddhist environment, viz. its indebtedness toward "reading practices.”

\section{Comparing scholasticisms}

1.1. A few steps in the direction of what can be called "comparative scholasticism" have already been taken in the past. Mention must be made in this connection of an important, though by now largely forgotten French scholar and philosopher, Paul Masson-Oursel (1882-1956), who has made a valuable attempt to approach scholasticism in a cross-cultural way as a phase in intellectual and philosophical development. ${ }^{4}$ According to him, scholasticism is not an "épisode, accidentel ou nécessaire, de notre civilisation issue du monde gréco-latin” (an episode that could be described), but an "aspect notable de la vie de l'esprit," an "état de civilisation," a "phase peut-être

\footnotetext{
* Most sincere thanks are due to François Chenet and Didier Monay for making various books and articles accessible, and to John Taber for carefully reading this paper and making insightful comments, many of which couldn't, however, be incorporated into its final version.

${ }^{1}$ Pollock 2015a: 1.

${ }^{2}$ Pollock 2015a: 22; see also Pollock 2015b: 114.

${ }^{3}$ See below, $§ 1.4$ and n. 27.

${ }^{4}$ See Masson-Oursel 1911 and especially Masson-Oursel 1920. On scholasticism and the debate on its nature, see Chenu 1993: 51-60 ("régime mental,” p. 52), De Rijk 1985: 82-105 (especially pp. 82-84), Schönberger 1991, and Solère 2002. Solère 2002 is perhaps the best overview of scholasticism to date. According to him, scholasticism refers to "l'ensemble des méthodes d'enseignement et de discussion en usage dans les écoles et les universités médiévales," and the "formes sous lesquelles s'est manifestée une très large partie de la production philosophique, théologique, juridique et scientifique du Moyen Âge” (Solère 2002: 1299ª).
} 
nécessaire de toute pensée” (a phase that could and actually must be defined). ${ }^{5}$ As a cross-cultural phenomenon, scholasticism is claimed to possess "une certaine généralité" 6 and to exhibit a remarkable degree of synchronicity in the Latin West, in India and in China, three cultural contexts in which it follows a "sophistic" phase with which it shares a fascination for language. According to Masson-Oursel, scholasticism can be defined as "un enseignement qui fonde son autorité sur la lettre d'un texte sacré, interprétée par un corps professoral voué à l'établissement comme à la défense d'une vérité religieuse et porté, pour y réussir, à mettre son concours dans la raison discursive ou formelle." 7 As we can see, Masson-Oursel does not subscribe to any "material” or doctrinal characterization of scholasticism (e.g., in terms of fides quaerens intellectum), but searches instead for the structural/formal features of this "pédagogie d'une orthodoxie": ${ }^{8}$ the subordination of science and philosophy to a clerically defined agenda, the primacy of the commentarial genre, an inclination for abstraction and formalism, ${ }^{9}$ a strong leaning towards encyclopedicity and systematic elaboration, an interest in unification and adaptation as well as apologetic concerns in a pluralistic environment.

1.2. Closer to us, and acknowledging a strong indebtedness to Masson-Oursel ("arguably the founder of the modern discipline of comparative philosophy” ${ }^{10}$ ), José Ignacio Cabezón has devoted two important contributions to the topic, ${ }^{11}$ arguing for scholasticism "as a general and cross-cultural category in the history of philosophy," or else as a "family of intellectual movements that are present in other cultures." 12 Cabezón describes Masson-Oursel's attempt as essentialistic ("scholasticism [could] be exactly defined by uncovering its essential qualities"), committed to historical evolutionism and Hegelian Eurocentricity (with its "goal of achieving objective, impersonal laws through the use of the comparative method"), thus as certainly "naive and outdated," but as "insightful and interesting” in many ways. ${ }^{13}$ Cabezón envisions scholasticism as being basically concerned "with reconciling the rational and the experiential aspects of human religiousness"14 and views in "rationalism and systematicity" 15 some of its key features. He distinguishes eight basic features of scholasticism: (1) "A strong sense of tradition," i.e., "self-identification with a specific tradition [...] and commitment to its preservation," 16 and defence against the intellectual assaults of others. (2) "A concern with language,” i.e., "with sacred language (scripture) and its exegesis and with language generally as medium of expression.” ${ }^{17}$ (3) "Proliferativity,” i.e., a "tendency to textual and analytical inclusivity rather than exclusivity," because scholastics opt "for broader [...] canons and for minute and detailed forms of analysis that leave no questions unanswered, no philosophical avenue unexplored." 18 (4) "Completeness and compactness," for, "related to the proliferative tendency of the scholastic mindset is the generally held scholastic tenet that the tradition is complete: that nothing essential to the project of salvation has been neglected." 19 (5) "The epistemological accessibility of the world," i.e., "the belief that the universe is basically intelligible.” ${ }^{20}$ (6) "Systematicity,” i.e., “order in exposition.” ${ }^{21}$ (7) "Rationalism," i.e., the commitment to reasoned argument and non-contradiction," for "scholastics consider reasoning to be integral to the religious path[:] the systematic elucidation of doctrine, the "elimination' of inconsistency, and the rational defense of tenets are perhaps the most central attributes of scholasticism.”22 (8) "Self-reflexivity,” for scholastics "are concerned not only with systematicity and rational argumentation, but with developing criteria for what

\footnotetext{
${ }^{5}$ Masson-Oursel 1920: 124, 124, 128, and 141, respectively.

${ }^{6}$ Masson-Oursel 1920: 124.

${ }^{7}$ Masson-Oursel 1920: 128.

${ }^{8}$ Masson-Oursel 1920: 129.

${ }^{9}$ Masson-Oursel 1920: 127.

${ }^{10}$ Cabezón 1994: 13-14.

${ }^{11}$ See Cabezón 1994 and Cabezón 1998.

${ }^{12}$ Cabezón 1994: 11 and 13, respectively.

${ }^{13}$ Cabezón 1994: 14

${ }^{14}$ Cabezón 1994: 19

${ }^{15}$ Cabezón 1994: 20. Note also Cabezón 1994: 21: "Scholastics are rationalists. [...] It is always possible for an opponent, real or imagined, to demand a reason, that is, to require that a particular doctrinal assertion be justified; and for the scholastic there is never any theoretical ground for denying the validity of such a request." According to him (ibid.), "[s]cholastic rationalism operates in large part to justify religious beliefs as expressed in doctrine.” This is in agreement with Chenu’s (1993: 55) characterization of scholasticism as a "forme rationnelle de pensée qui s'élabore consciemment et volontairement à partir d'un texte estimé comme faisant autorité.” Note the Dominican father’s striking formulas about the place of reason in scholasticism: "par un curieux paradoxe, cette méthode d'autorité voisine avec une extrême confiance en la raison" (1993: 57); “[t]oute la scolastique est mue par une confiance en la raison” (1993: 58). In the context of the "formule disputationnelle,” Solère (2002: $1309^{\mathrm{b}}$ ) speaks of a "rationalisme de la scolastique” (see also Schönberger 1991: 73-80).

${ }^{16}$ Cabezón 1998: 4. See also Cabezón 1998: 20-21.

${ }^{17}$ Cabezón 1998: 5.

${ }^{18}$ Cabezón 1998: 5.

${ }^{19}$ Cabezón 1998: 5 .

${ }^{20}$ Cabezón 1998: 5. According to Cabezón 1994: 20, "at the very least everything that is of soteric importance is understandable through rational inquiry."

${ }^{21}$ Cabezón 1998: 5 .

${ }^{22}$ Cabezón 1998: 6. See also Cabezón 1994: 22.
} 
constitutes a rational argument, that is, with logic as a second-order discourse.”23 Additionally, Cabezón stresses the need for unity and synthesis, for "scholastics are usually dealing with large quantities of disparate textual material that is often contradictory. Part of their self-imposed task is to synthesize this material into an ordered whole." 24

1.3. In the present writer's opinion, comparative scholasticism should not, at least not primarily, aim at comparing doctrinal tenets and philosophical arguments, but rather at considering the intellectual cultures that were responsible for the formation, the development, and the overall physiognomy of law, the sciences, theology, and philosophy in the two contexts. ${ }^{25}$ This includes the institutional environment, the teaching and scholarly practices, the many ways in which knowledge was produced, stored, enriched and made to fructify, etc. In other words, the ambition is to compare, say, structures ${ }^{26}$ or, perhaps, "dispositifs de production," rather than intellectual contents. In doing so, the Western medieval environment is to be approached and constructed as a heuristic tool, thus resorting to what is well or at least better known in order to draw research and interpretative hypotheses concerning the social and institutional conditions that presided over the formation and the development of specific ideas in the Buddhist context. In particular, the study of Latin medieval scholarly practices is very likely to help us better assess the extent to which Buddhist philosophical and more generally "śāstric" texts reflect teaching techniques and practices.

1.4. Among the many factors that make the Middle Ages so appealing in this connection, one could mention the fact that its philosophical traditions developed in a constant and multi-faceted dialogue with a revelation-if not revelations, if one considers its attitude toward the Aristotelian corpus from the $13^{\text {th }}$ century onward, and the fact that Jews and Muslims were involved in the process - i.e., the fact that dialectical argumentation and experience had to constantly invent new ways of coming to terms with the Bible, the Church Fathers, and, increasingly, Aristotle. In dependence on this, the Latin Middle Ages developed as an intellectual culture in which commentarial activity played a crucial role in the interpretation and the appropriation of earlier authorities—or, as Bernardo C. Bazán says, "une culture théologique et scientifique centrée sur des textes, [...] une culture en situation herméneutique.”27 The Middle Ages inherited normative divisions of the sciences (the most famous one distributing them into the trivium and the quadrivium), each field of knowledge having its own auctoritates to be relied and commented upon, and intellectually recontextualized. ${ }^{28}$ Mention should also be made of the primacy of disputation as a method for teaching, interpreting, inquiring and, in one sense at least, debating and polemicizing. ${ }^{29}$

\footnotetext{
${ }^{23}$ Cabezón 1998: 6.

${ }^{24}$ Cabezón 1994: 21.

${ }^{25}$ For a somewhat programmatic essay on comparative scholasticism, see Eltschinger 2017.

${ }^{26}$ The word is used, by the way, by Marie-Dominique Chenu (1993: 66).

${ }^{27}$ Bazán 1985: 25, quoted in Solère 2002: $1301^{\mathrm{b}}-1302^{\mathrm{a}}$.

${ }^{28}$ On the different classifications of knowledge, see Weijers 2015: 45-59. For discussions of authority in scholasticism, see, e.g., De Rijk 1985: 87-89, Schönberger 1991: 103-108, Chenu 1993: 106-131; on the authorities specific to the different disciplines, see, e.g., De Rijk 1985: 8996, Riché/Verger 2013:119-145, Weijers 2015: 61-75.
}

${ }^{29}$ See Bazán 1985, and especially Weijers 2013 and 2015: 107-137. The word disputatio can refer to at least three very different discursive/dialogical situations. First, two forms of disputatio should be distinguished, the "eristic/dialectical disputation” (see Weijers 2013: 76-78), which bears no connection with commentarial activity and "clearly seems to follow the ancient tradition of dialectical jousts as described by Aristotle and transmitted by Boethius” (Weijers 2013: 95), and the "scholastic disputation” which, consisting in "opposing contradictory arguments" (ibid.), is "aimed at finding the truth of a deep understanding of the problem" and searching for "the right answer to real problems or to teach dialectic and philosophy" (Weijers 2013: 108). The eristic disputation develops in the context of the logica modernorum, in the logical compendia called artes disputandi, where "the practice of the art of disputation is the central theme of the discussion" (Weijers 2013: 76) and "the disputatio is explicitly described as a discussion between an opponent (opponens) and a respondent (respondens)" (Weijers 2013: 77). One of its four types is the "dialectical disputation,” "a duel between an opponent and a respondent” (Weijers 2013: 77). In the thirteenth century, the eristic disputation gives rise to the ars obligatoria, obligationes constituting "the logic of a certain form of disputation in which each participant tried to induce the other to contradict himself [...]. Serving as a means to teach and check the correctness of dialectical rules, it can be considered both as an exercise and as a preliminary stage for real (i.e., doctrinal) disputation [...]" (Weijers 2013: 77). It is important to note that the scholastic disputation "is not a dialectical duel between two opponents, but the discussion of a question-using dialectical tools of course - between a master and his students or between several masters and bachelors (i.e., students having obtained the first degree)" (Weijers 2013: 121-122). According to Weijers (2013: 122), the scholastic disputation differs from the eristic in at least four ways: "First, it is generally the disputation of a question arising, at least in the beginning, from the reading of texts, especially in the faculties of theology and arts; often it concerns difficulties arising from the text, apparent contradictions or conflicting interpretations. In the faculty of law, it concerns concrete juridical cases, as it did in the twelfth-century law schools [...]. Second, it aims at determining (or teaching) the truth, at finding the right answer to the question; its use of dialectical argumentation, especially syllogisms, is geared wholly to this end. Third, the basic structure of the scholastic disputation is quite different from the eristic disputation: after the formulation of the question, arguments are given both for the affirmative and for the negative answer, after which the master gives his solution (usually one of the two positions discussed, but he may propose an alternative by means of distinction) and refutes the arguments counter to this opinion. Fourth, at least three participants figure from an early stage: the master, who proposes the questions, presides over the discussion and gives his solution, the respondent, who gives a preliminary answer, and the opponent, who attacks the respondent's arguments. In more important disputations, several respondents and opponents appear [...]. These two forms of disputatio should be distinguished from "public debates, [...] a kind of dialogue on philosophical subjects conducted before a public” (Weijers 2013: 96; on public debates, see also Weijers 2013: 82-84). According to Weijers (2013: 82), "[t]hese public debates may have been inspired by the eristic disputation, which also sometimes took place before an audience. However, they were controversies about questions of philosophical interest and not dialectical jousts, and did not follow 
Moreover, most of the pre- $14^{\text {th }}$-century medieval intellectuals were clerics, be it simply because they were granted legal privileges as university scholars. And although, in contradistinction to most of what we know from the Buddhist context, all of them did not belong to the regular clergy, ${ }^{30}$ many important philosophers and theologians from the $13^{\text {th }}$ and $14^{\text {th }}$ centuries actually belonged to the mendicant orders of the Dominicans or the Franciscans and thus were as much committed to promoting their own monastic order as they were to defending their own personal views.

\section{From lectio to disputatio}

2.1. The teaching methods resorted to by medieval masters have received a lot of critical attention thanks to the work of scholars such as Martin Grabmann, Palémon Glorieux, Lambertus Marie De Rijk, Bernardo C. Bazán and, closer to us, Olga Weijers, to whose decisive contributions the following presentation is heavily indebted. In particular, these and other specialists have shown how the origin of the disputation, admittedly one of the practices most characteristic of the medieval academic landscape, could be traced to the lectio ("which means not only the reading but also the explanation of and comments on a text" ${ }^{31}$ ), from which, in the form of the quaestio disputata, it was gradually detached and gained autonomy in the $12^{\text {th }}$ or $13^{\text {th }}$ century depending on the contexts. ${ }^{32}$ As remarked almost fifty years ago by P. Glorieux, “[l]a dispute est née de la leçon, par l’intermédiaire de la question,” ${ }^{33}$ a hypothesis that since then has been widely confirmed: "Such questions raised by the master during the lectures and discussed immediately in the classroom are called quaestiones; the term quaestio disputata (disputed question) is generally reserved for the written form of questions that have been discussed, to be distinguished from the discussion itself, which is called disputatio (disputation). [...] When the questions are completely separated from the explanations of the texts, not only in time but also in subject, and thus become an independent exercise, we see the birth of the disputatio in the sense of the scholastic disputation." ${ }^{34}$ According to Anthony Kenny, "[p]erhaps the disputatio simply grew out of the other and older vehicle of professional instruction: the lectio, or lecture. In the course of expounding a text a commentator, from time to time, is bound to encounter difficult passages which set special problems and need extended discussion. When we are dealing with a sacred or authoritative text, the difficult passages will have given rise to conflicting interpretations by different commentators, and the expositor's duty will be to set out and resolve the disagreements of previous authorities. Thus the quaestio arises naturally in the course of the lectio, and the disputation and the lecture are the institutionalized counterparts of these two facets of a method of study oriented to the interpretation of texts and the preservation of tradition." 35 This interpretation of the historical development of the disputatio out of the quaestio via the quaestio disputata is further confirmed by $\mathrm{O}$. Weijers, according to whom "there seems to be no doubt that quaestiones developed out of commenting on basic texts during the lectures. The divergence or obscurity of the authoritative texts suggested that comparison and critical analysis, along with dialectic, was used. This provided the occasion for a discussion on a theological issue, in which dialectic played a role-a discussion about a quaestio. The question here was thus initially a problem of interpretation. [...] With the help of dialectic, from Abelard onwards, the masters developed a complete method of teaching and research based on the systematic and well organised discussion of such quaestiones. [...] At the same time the collections of Sentences (the most famous was Peter the Lombard's) established a form of systematic theology in which we also find questions arising from the discrepancies between authorities and being discussed with a certain amount of dialectical argumentation." 36 Thus "the divergence between different

the systematic format of the quaestio [...]. They were discussions in which two opponents expressed different opinions, defending them with arguments based on authorities or on dialectical reasoning, but they did not obey certain rules and thus differ from both types of disputation we saw above. Let us call them 'debates' to mark the difference (although they too are often called disputatio in the written reports)." Importantly, "[w]e may deduce that in these debates one of the two participants was declared victorious, a detail that reminds us of the victories reported by Peter Abelard in his autobiography: he not only defeated his master William of Champeaux in a discussion about universals, but later sent his own students to debate with the same master and his pupils” (Weijers 2013: 83).

${ }^{30}$ Philosophers such as Arcața ( $8^{\text {th }}$ century) and Śankaranandana $\left(10^{\text {th }}\right.$ century?) could have been exceptions to this in that, though Buddhists from a religio-philosophical, doctrinal point of view, they were and remained brahmins.

${ }^{31}$ Weijers 2013: 84. See also Weijers 2015: 79-80, Glorieux 1968: 108-122, and Chenu 1993: 67-71 (p. 67: "la lectio est acquisition de la science par l'étude des textes. [...] Enseigner, c'est lire, lire au sens technique: le professeur 'lit' son texte; son cours s'appelle une lectio, et il se nomme expressément lector.”).

32 See Weijers 2013, esp. pp. 84-88, and Bazán 1985: 31-34. Weijers points to the period between 1150 and 1200 and the circles of Simon of Tournai and his successors (Weijers 2013: 87), the School of Laon for the "resolution of theological problems during the exposition of the Bible” (Weijers 2013: 84), Abelard’s famous Sic et non, which “sets out to contrast authorities, principally the Church Fathers” (Weijers 2015: 95-96), and other theologians such as Gilbert of Poitiers, Stephen Langton and Robert of Melun.

${ }^{33}$ Glorieux 1968: 123. According to Chenu (1993: 67), “[l]e ‘style’ scolastique peut être ramené à ses éléments simples, [...] à trois procédés, dont la progression figure d'ailleurs à la fois leur genèse historique et leur progrès technique: on est passé de la lectio à la quaestio, puis de la quaestio à la disputatio." See also De Rijk 1985: 99-101 and Solère 2002: $1302^{\mathrm{a}}$

${ }^{34}$ Weijers 2013: 87.

${ }^{35}$ Kenny and Pinborg 1982: 25.

${ }^{36}$ Weijers 2013: 85, summarizing Bazán 1985. 
authorities or between different parts of the same authoritative text” ${ }^{37}$ likely was one of the driving forces in the development of the quaestio as an exegetical and doctrinal device destined to "to teach the meaning of the text but also to try to understand and clarify the problems implied by it." 38

2.2. The presence of a contradiction and the discussion of antithetical propositions are definitory features of the question. These were foreshadowed in the writings of Aristotle ${ }^{39}$ and especially Boethius who, in his In Topica Ciceronis Commentaria, defined the quaestio as a dubitabilis propositio, "a proposition which one can doubt." 40 And in his De differentiis topicis, the same Boethius characterizes a question as in dubitationem ambiguitatemque adducta propositio, "a proposition leading to doubt and uncertainty." ${ }^{41}$ Thus according to Boethius, a question always entails doubt and contradiction: "A question comprises at the same time an affirmation and a negation; for by the very fact that it is subject to doubt it seems to include a contradiction" (ibid., 1049 B). This contradictoriness is reflected in the most frequent expression of the question, the utrum... an... ("whether... or...") formula. In the first half of the twelfth century, Gilbert of Poitiers (1076-1154) elaborated on Boethius's definitions. While agreeing that a contradiction is always involved in a question, he emphasized that "doubt is only present when valid arguments seem to support both parts of the question, the pro and the contra." ${ }^{42}$ Hence the characteristic form of the question from the first part of the $13^{\text {th }}$ century onward: "First the question—which could be answered by yes or no-was formulated, then arguments (based on authoritative texts or on dialectical reasoning) for the two possible answers were given. Next the master provided a 'determination' or 'solution' (i.e., the definitive answer to the question along with the justification), and finally there was a refutation, also given by the master, of the arguments given for the opposite position." ${ }^{33}$ This situation helps define both disputation as an art or a method and dialectic as the technique of argumentation proper, since "disputation is the art of discussing correctly —in other words to use serious argumentation to debate doubtful or contradictory propositions and prove which position is valid and which not. [...] [T] his art is the art of dialectic, since Ancient times considered the foundation of all rational inquiry." 44 In his De differentiis topicis, Boethius defined an argument as "a reasoning (ratio) that makes a dubious matter trustworthy" (argumentum autem ratio est quae rei dubiae faciat fidem) ${ }^{45}$ In the context of the discussion of a question, ratio as rational argument or dialectical reasoning (particularly syllogisms) is appealed to in addition to other sources for valid argumentation, such as auctoritas, (the quotation of an) authority or authoritative text, and experientia, experience, "that is to say perception of the real world by the sense," ${ }^{46}$ or "experimental verification, meaning essentially the observation of reality, the way in which we experience reality." 47

2.3. What was to become the disputed question, i.e., what was called dubia, quaestiones or dubitationes, originally was allotted a specific (and rather limited) part toward the end of the commentary, at least in the commentaries in the form of lectiones ${ }^{48}$ that were very common in the Paris Arts faculty between 1230 and 1260: "Commentaries in the form of lectiones [...] resembled the traditional literal explanations. They were divided into units of reading or lessons (lectiones), and each lectio had several fixed elements. The divisions of the commented passage (into

\footnotetext{
${ }^{37}$ Weijers 2013: 85-86.

${ }^{38}$ Weijers 2013: 86. Among the other factors, mention can be made of questions concerning “difficult points, obscure expressions or intriguing features” (ibid.). See also Chenu 1993: 71, and Panofsky's interesting remarks in Panofsky 1957: 65ff.

${ }^{39}$ As remarked by Weijers (2013: 74), opposing pro and contra arguments in order to arrive at a solution comes very close to "the aporia method of Aristotle," sometimes referred to as "diaporematic," where "diaporein means to find a way amidst thoroughly explored difficulties," whereas "the solution is called euporia, which means 'solve the aporia in a satisfactory way”” (Weijers 2013: 35, referring, e.g., to Metaphysics III,1, Topics I,2, and Ethics VII,1, where "one presents a problem [aporia], introduces the conflicting opinions of philosophers, solves the difficulties and formulates the new opinion” [Weijers 2013: 36]). Note, by the way, that "[a]poria was translated by Boethius as dubitationes, or doubts, in his version of the Aristotelian treatise On interpretation" (literally, an aporia is "a difficulty obstructing the way" [ibid.], i.e., "problems arising from the fact that the savants of the past disagree about them or that valid arguments can be found for both sides" [ibid.]). Schönberger (1991: 52) describes the question as “eine durch einen Widerspruch erzeugte Aporie.” On the "method of the aporiai," see Weijers 2013: 35-38. On the relationship with Aristotle’s aporia, see Chenu 1993: 79.

${ }^{40}$ Patrologia Latina 64, 1048 D, quoted and translated in Weijers 2013: 75.

${ }^{41}$ Patrologia Latina 64, 1174 B, quoted in De Rijk 1985: 227, n. 25.

42 Expositio in Boecii librum de trinitate (ed. Häring, p. 63, quoted in Schönberger 1991: 53, n. 78), translation Weijers 2013 : 79.

${ }^{43}$ Weijers 2013: 124. As Chenu points out, objicere/objectio do not always have the meaning we are familiar with: "objicere, c'est inducere rationes, donner des raisons pour l'une ou l'autre partie, et non pas opposer un fait ou un raisonnement à une thèse au préalable établie" (Chenu 1993: 79). In the same way, the sed contra arguments are not aimed at refuting the objections; rather, they consist in rationes quae sunt ad oppositum: “La seconde série d’arguments n’est pas contre la première série, elle est pour la seconde partie de l'alternative et ne s'oppose qu'indirectement aux arguments donnés pour la première. Ce qui s'oppose directement aux arguments combattus du point de vue de la thèse établie dans la détermination, ce sont les réponses qui suivent le corps de l'article, les responsiones ad objecta, c’est-à-dire réponses aux arguments [...], qu'ils soient de la première ou de la seconde série, dès lors qu'il s'écartent de la thèse” (Blanche 1925: 177-179, quoted in Chenu 1993: 80).

${ }^{44}$ Weijers 2013: 105.

${ }^{45}$ Patrologia Latina 64, 1174 B, quoted and translated in Weijers 2013: 75.

${ }^{46}$ Weijers 2013: 101.

${ }^{47}$ Weijers 2013: 142-143, referring to Imbach 2010

${ }^{48}$ See Weijers 1996: 42-44.
} 
several sections and subsections) are set out at the beginning of each lectio. The exposition or paraphrase (expositio or sententia in speciali) then follows; this is sometimes preceded by the sententia (in generali; alternatively called the intentio), in other words the general meaning, so that the reader is given the broad sense of the passage before the commentary moves to literal analysis. The final section, sometimes following an ordo or ordinatio (describing the place of the passage within the text and the order of its parts) contained the dubia or quaestiones, questions or uncertainties arising from the text." 49

\section{The Theory of Indian Buddhist Commentary}

3.1. As we have seen above, P. Masson-Oursel and J.I. Cabezón have insisted on commentarial activity as a defining feature of scholasticism regarded as a transcultural phenomenon, and cursory comparisons between Indian and medieval commentaries are not rare, as is testified by some pages of Madeleine Biardeau, likely the greatest among $20^{\text {th }}$-century French exponents of Indian philosophy. ${ }^{50}$ The centrality, the abundance and the diversity of commentarial activity have long been recognized as an essential component of intellectual life in ancient India understood as a (set of) traditionalist culture(s) averse to anything perceived as "new." As was pointed out by many specialists, however, commentaries often were, in India as elsewhere, a vehicle for (more or less discrete) innovation, and the adjective "new" was by no means universally perceived as deprecatory. ${ }^{51} \mathrm{Be}$ that as it may, in spite of several seminal studies, the Indian commentary has not received the systematic attention it deserves. ${ }^{52}$ As even a superficial look at Indian commentaries suggests, raising objections and responding to them belong to the most congenial tasks and, as a point of fact, actual activities of Indian commentators. Here again, studies, and especially statistically based analyses of specific corpora are missing, and the extent to which this objection-andanswer structure has been normatively theorized as a mandatory feature of commentaries remains unclear. There is, however, at least one ancient Indian textual tradition that consciously theorized it as a necessary part of a commentary. Indeed, from at least the *Vivaranasangrahaṇi (VivSg, Tib. rNam par bśad pa bsdu ba) of the Yogāa ārabhümi (YoBh, 4 ${ }^{\text {th }}$ century $\mathrm{CE}$ ?), ${ }^{53}$ a tradition of Indian Buddhist scholastics has construed codyaparihära, "responding to(/refuting) objections," ${ }^{54}$ as a necessary component of Buddhist canonical exegesis, a component that, as its Latin counterparts, was gradually allotted the final part of a commentarial sequence. Interestingly, this aspect of a commentary was also regarded by Indian Buddhist intellectuals as triggered by contradictions (virodha) - either in the form of internal inconsistencies or in the form of contradictions with reason(ing). And as we shall see, this doctrinal and apologetic complex can also be shown to be at the heart of later Buddhist philosophy. In other words, a defining feature of scriptural commentary can be regarded, if not as having given rise directly to philosophy in the Buddhist environment, at least to have become an essential element of the Buddhist philosophers' way of accounting for their own philosophical and apologetic enterprise.

Strictly speaking, the VivSg is dedicated, not so much to commentary as (a) literary genre(s), as to the way in which a Buddhist preacher (dharmabhānaka) should explain the canonical scriptures in a catechetic, apologetic

\footnotetext{
${ }^{49}$ Weijers 2015: 81; Weijers 1996: 42.

${ }^{50}$ In her influential presentation of classical Indian philosophy in the Encyclopédie de la Pléiade, M. Biardeau quotes É. Gilson (1969: 83) and Thomas Aquinas (Commentary on Ethics, I, 2, as quoted in Chenu 1959: 135; Biardeau 1969: 87-88). She writes (1969: 87): “Le travail philosophique [en Inde ancienne, VE], de plus, semble s'être fait moins dans une méditation solitaire et désintéressée que dans la relation de maître à disciple, où le maître expose sa doctrine en y incluant les débats avec ses adversaires. C'est pourquoi les commentaires philosophiques prennent une forme essentiellement scolastique qui tient à la fois de la leçon et de la dispute médiévales, tandis que les textes indépendants rappelleraient plutôt les disputes 'quodlibétiques."” Biardeau alludes several times to scholasticism: "Disons donc simplement que la pensée brahmanique n’entre pas telle quelle dans nos catégories. En deçà de la distinction entre philosophie et théologie, elle se présente néanmoins comme une scolastique de plus en plus subtilement élaborée à partir de textes religieux intangibles" (1969: 92). "Les [les systèmes philosophiques ,VE] considérera-t-on alors comme de la 'théologie', en tenant compte de leur relation essentielle à une révélation? Ce serait encore rester dans une problématique occidentale où, même au Moyen âge, la distinction entre une pensée 'naturelle' et rationnelle pure et une pensée théologique s’appuyant sur le donné révélé est claire” (1969: 89). "Parce qu’elle avait rencontré la philosophie grecque (peut-être la seule philosophie spéculative ancienne qui se soit présentée comme uniquement rationnelle, sans présupposé religieux), la pensée médiévale chrétienne savait parfaitement qu'il y avait deux ordres de connaissance: la connaissance de foi, fondée sur un donné révélé partiellement perméable au travail de l’intelligence humaine, mais que celle-ci n’eût jamais pu découvrir, et la connaissance naturelle, où la raison s’exerce souverainement sur l'expérience qu'elle a du monde et construit sa vérité avec les critères de validité interne qu'elle se donne, n’ayant d'autre limite que son pouvoir actuel de connaissance" (1969: 90). Other direct allusions to scholasticism in indological scholarship include, e.g., Gerhard Oberhammer, Ernst Prets and Joachim Prandstetter's three-volume Terminologie der frühen philosophischen Scholastik in Indien (1991-2006), and Gary Tubb and Emery R. Boose’s Scholastic Sanskrit, A Manual for Students (2007).

${ }^{51}$ See, e.g., Biardeau 1969: 83-96, Ratié 2013: 425-438, and Seyfort Ruegg forthc.

52 See Chenet 1998, Hulin 2000, Preisendanz 2008, and Pollock 2015b.

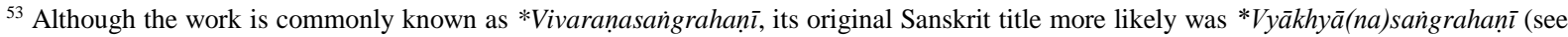
Delhey 2013: 539, and below, n. 56). On the YoBh, a bulky and essentially composite summa of early Buddhist idealism (Yogācāra, Vijñānavāda), see Schmithausen 1969 and Delhey 2013; on the VivSg, see Nance 2012: 167-212, on which significant parts of what follows are based.

${ }^{54}$ Or "objections and responses," which amounts to the same, depending on the Tibetan translation of codyaparihāra: rgol ba'i lan (see below, nn. 56-57), reflecting an analysis as a genitive tatpurușa, and brgal ba dá lan (see below, n. 69), reflecting a dvandva interpretation.
} 
and proselytic vein. ${ }^{55}$ The VivSg starts with the following summary of its contents: "What is the summary of explanation ( ${ }^{*} v y \bar{a} k h y \bar{a}[n a]$ saingraha[nī $\left.]_{\mathrm{VE}}\right)$ ? A general account [encompasses]: 1. The corpus 1.1. Phrasing 1.2. Meaning 2. Explication 2.1. Teaching 2.2. Prompt 2.3. Meaning 2.4. Responding to objections 2.5. Connection 3. The dharma preacher 4. Exposition 5. Assembly 6. Listening 7. Brief and extensive praise of the Buddhas 8. Rewards of training." ${ }^{56}$ Explaining all these items would bring only very little in the present context. Let it be noted that "responding to objections" is one of the five aspects of "explication," which the VivSg presents as follows: "Having first investigated the corpus of buddhavacana ["Word of the Buddha" vE], one should seek out all ten forms of meaning —or whichever is suitable—in the scriptural texts (gsun rab, *pravacana). Having done so oneself, one should teach these to others. Accordingly, a dharma preacher should engage in the practice [of teaching] by explicating in five ways those sütras [...]. First, he should expound the teachings. After that, he should expound the prompt. After that, he should expound the meaning. After that, he should expound responses to objections. After that, he should expound connections." ${ }^{57}$ As we can see, the Buddhist preacher first "privately" analyses the twelvefold $\operatorname{canon}^{58}$ (dvādaśängapravacana) according to, or by identifying, ten different kinds of meaning. ${ }^{59}$ It is only once he has secured this understanding for himself that he turns to exegesis proper (1) by locating the explicated text in the twelve canonical "genres" or registers, (2) by identifying the "prompt," i.e., discerning the motivation (turn one away from desire; instruct him; gladden him) behind the explicated text, (3) by ascertaining its summary and literal meanings (the latter by "indicating synonyms, $[\ldots]$ the corpus, $[\ldots]$ etymological derivation, and analyzing into aspects"), (4) by formulating and answering possible objections, and (5) by demonstrating its syntactic "connection" and semantic completeness.

Accounting for what triggers objections (whether expressed by oneself or by others ${ }^{60}$ ), our text resorts, in addition to simple misunderstanding, doubtful synonymity(?) and reconditeness, ${ }^{61}$ to two types of contradiction. According to the VivSg, "[i]n brief, objections are of five kinds. [Not understanding the meaning:] There is nonunderstanding of the meaning, where a person who has failed to understand inquires, 'What is the meaning of this phrase?' [Verbal contradiction:] There is verbal contradiction, where [it is objected that] 'what is said by the Blessed One here [contradicts] what he previously said on another occasion.' [Contradiction with reason:] There is contradiction with reason, where a passage appears to contradict the four modes of reasoning. [Appearance (in) multiple parts:] There is the appearance [of one meaning] across multiple parts [of a text or texts], as [when one hears], 'The Blessed One taught this very meaning in this or that [place], with many synonyms.' [Extremely recondite:] [Finally, one may encounter objections] due to an extremely recondite [teaching]—e.g., 'What is the inner self? Does it exist, abiding as permanent, stable, eternal, and truly real?"62 The first type of contradiction relates to what is known among Indian scholastics as pürväparavirodha, i.e., "contradiction/incompatibility between successive

\footnotetext{
${ }^{55}$ For a description of the Buddhist preacher in the VivSg, see Nance 2012: 187-188.

${ }^{56}$ YoBh, VivSg D 'i 48a1-2: rnam par bśad pa bsdu ba gan் źe na / spyi sdom ni /lus dan் rnam par bśad pa dan்/ /tshig 'bru dan் ni don ñid

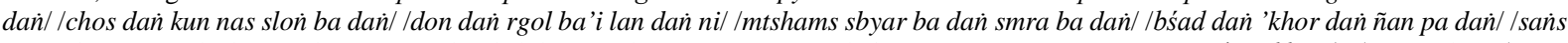

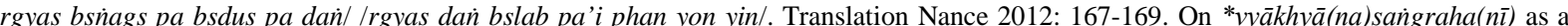
rendering of Tib. rnam par bśad pa bsdu ba, cf. ASBh 142,11: vyākhyāsañgrahamukham, and see above, n. 53. As noted by Nance himself (2012: 254, n. 1), he has "shifted the order in which these topics are listed in the opening verse to track the order in which they are treated in detail in the ensuing text."

${ }^{57}$ YoBh, VivSg D 'i 54a1-3: de ni re źig sañs rgyas kyi bka'’i lus yin te / de'i phyir gsuñ rab la don bcu po de dag thams cad dam gan் yan் run ba yon்s su btsal bar bya'o // de ltar bdag ñid kyi don du yon்s su btsal nas gźan dag la bstan par bya'o // de ltar [...] mdo sde la chos smra bas rnam pa lnas rnam par bśad pas 'jug par bya ste / dan் por chos brjod par bya'o // de'i 'og tu kun nas slon் ba brjod par bya'o // de'i 'og tu don brjod par bya'o // de'i 'og tu rgol ba'i lan brjod par bya'o // de'i 'og tu mtshams sbyar brjod par bya'o //. Translation Nance 2012 : 181. See also YoBh, VivSg D 'i 48a3 and Nance 2012: 169.

${ }^{58}$ The twelve "members” (an்ga) are: (1) sütras, (2) melodic verses (geya), (3) prophecies/predictions (vyākaraṇa), (4) verses (gāthā), (5) inspired utterances (udāna), (6) circumstantial narratives (nidāna), (7) parables/stories (avadāna), (8) ancient narratives (itivrttaka), (9) accounts of former lives (jātaka), (10) extensive scriptures (vaipulya), (11) fabulous accounts (adbhutadharma), (12) instructions (upadeśa). The VinSg explains "instructions" as “matrices” (mātrkāa) and abhidharma, i.e., Buddhist dogmatics. See Nance 2012: 181-183, and more generally Lamotte 1976: 159-161 and Nattier 2004.

${ }^{59}$ On the ten types of meaning, see Nance 2012: 174-180.

${ }^{60}$ According to YoBh, VivSg D 'i 55b5: rañ gis glèns pa'am gźan gyis brgal ba.

61 The Tib. expression śin tu lkog tu gyur pa generally renders Skt. atyantaparoksa, "radically imperceptible,” which, in later Buddhist epistemology, refers to those states of affairs that are unempirical/transempirical, i.e., neither directly perceptible (pratyaksa) nor inferable (anumeya). This interpretation may, however, be somewhat anachronical, for the example adduced by the VivSg, the (inner) self (*adhyātma, *ādhyātmika?) does not, properly speaking, point to a radically imperceptible object, but rather to what is technically known as an avyākrtavastu or "unanswered question/point" (as in questions such as "Is the soul different from the body or not?," "Does a Buddha survive after death or not?”). The VivSg's explanation of the response to be given to this type of objection leaves no doubt about this (YoBh, VivSg D 'i 56a2-6, see Nance 2012: 186-187).

${ }^{62}$ YoBh, VivSg D 'i 55b5-7: de yan் mdor bsdu na rnam pa linas rgol te / don ma rtogs pa ni ma rtogs pas tshig 'bru 'di’i don ci yin źes rgol lo // tshig 'gal bas ni 'di lta ste bcom ldan 'das kyis snar ni gźan du gsuñs la 'dir ni gźan du gsun்s so źes bya ba lta bus so // rigs pa dan் 'gal

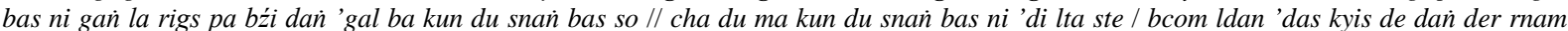
gran்s du mas don de ñid yon்s su bstan pa lta bus so // śin tu lkog tu gyur pas ni 'di lta ste / nan் gi bdag gan் yin pa de ni rtag pa dan் brtan ${ }^{1}$ pa dan் ther zug dan yan் dag pa de kho na bźin du gnas par 'gyur ba de lta bu yod dam źes bya ba la sogs pas so //. ${ }^{1} \mathrm{em}$. : bstan D. Translation Nance 2012: 185
} 
statements," a type of rhetorical defect generally regarded as a hallmark of untrustworthiness. ${ }^{63}$ According to the VivSg, this type of objection is answered by exhibiting the intention underlying these apparently contradictory loci. ${ }^{64}$ As for contradiction with reason (yuktivirodha), it points to a given statement's failure to meet the requirements of reason(ing) (yukti), an important concept that, as we shall see, was given at least two different interpretations within Buddhist scholastic circles. The type of reason(ing) involved in our passage plays on two possible meanings of the Sanskrit word yukti = yoga (and the English word “reason”): reason as causa fiendi and reason as causa cognoscendi, the latter (the logical one) being understood as relying on, or reflecting, the former (the ontological one). This type of reason(ing) is regarded as fourfold: reason(ing) (based) on the realization of an effect (kāryakaraṇayukti), reason(ing) (based) on mutual dependence between entities (apekșāyukti), reason(ing) that proves by means of arguments (upapattisädhanayukti), and reason(ing) (based) on the true nature of things or the way things are (dharmatāyukti). ${ }^{65}$ Unfortunately, the VivSg has only very little to say about the kind of answer that should be given in such a case: "[Contradiction with reason:] One should offer a response by indicating a kālāpadeśa, by indicating the four modes of reasoning, and by indicating the connection between the cause and the result, saying 'This is the result of such-and-such a cause." 66 This brief description entails three elements. While responding, the explicator first can point to the fact that the claim underlying the objection is simply unbuddhistic by showing that it is a kālāpadeśa, literally a "black/detrimental teaching." Teachings of that sort are purported by some alleged (or self-appointed) authority to have been made by the Buddha himself and can be shown, on closer analysis, neither to conform to the sermons (sütra) and the discipline (vinaya) preached by the Buddha nor to reflect the way things actually are (dharmatā) ${ }^{67}$ Second, the explicator can answer by showing that the statement under scrutiny actually conforms with the standards of rationality as defined by the above-mentioned four types of reason(ing). Finally, he can prove the rationality of the commented text by resorting to causality, i.e., by demonstrating that things actually behave as they are said to do. As one can see, the three strategies overlap to a great extent: "the way things are" (dharmatā) is common to methods 1 and 2, and methods 2 and 3 both resort to causality. In other words, demonstrating that the scriptural statement commented upon does not contradict reason(ing) amounts to showing that it is consonant with the rest of Buddhist scriptures and that it conforms to reality itself interpreted, in a characteristically Buddhist way, as an entangled web of causal processes.

3.2.1. There is little doubt that Vasubandhu (active around 400 CE?), himself a Yogācāra author, knew the VivSg as he composed his influential Vyākhyāyukti (VY), a manual of scriptural exegesis with a strong leaning toward apologetic on behalf of the Mahāyāna (the "Great Vehicle" toward salvation and enlightenment). ${ }^{68}$ Vasubandhu's VY is not only far more exhaustive than the VivSg in its treatment of codyaparihära; it is also working with a fairly different — one is tempted to say a new — concept of rationality. The treatise starts with the following words: "How should one discuss the sütras? [One should do so] via five aspects ( $\bar{a} k \bar{a} r a)$. One should state the purpose (prayojana) of the sūtra; the summary meaning (piṇ̣̂̂rtha); the meaning of the phrases (padārtha); connections (anusandhi); and the two: objections and responses (codyaparihāra). The two-objections and responses—are collapsed into one [aspect], since the responses offered pertain to the [particular] objections [raised]. [...] From the objections and responses, [one may understand] that [the text] does not contradict reason and that there is no contradiction between those [texts] that are earlier [and] later." ${ }^{69}$ As we can see, (1) Vasubandhu re-organizes the VivSg list by replacing "teaching” and "prompt” by "purpose," by dividing "meaning” into "summary meaning” and "meaning of the phrases," and inverting the order of items 4 and 5, “objections and responses” and

\footnotetext{
${ }^{63}$ On pürvāparavirodha, see, e.g., Eltschinger 2007: 108-109.

${ }^{64}$ YoBh, VivSg D 'i D56a1-2: 'tshig 'gal ba la ni dgon்s pa yan் dag par bstan pas rjes su mthun par bya ba'o // tshig 'gal ba la dgon்s pa yan்

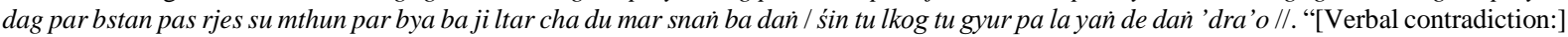
[Passages] should be made to concord via indicating the intention [underlying them]. One should proceed likewise in cases of appearance in multiple parts and extremely recondite teachings.” Translation Nance 2012: 186.

${ }^{65}$ On the four types of reason(ing), see, e.g., Sakuma 1990: II.99-102, nn. 596-605, Yoshimizu 1996: 114-119, n. 85, Deleanu 2006: II.494495, n. 74, Eltschinger 2010a: 555-558.

${ }^{66}$ YoBh, VivSg D ’i D56a2: rigs pa dan் 'gal ba ni nag po bstan pa dan rigs pa bźi bstan pa dan che ge źig gi 'bras bu 'brel pa bstan pas lan gdab par bya ba'o //. Translation Nance 2012: 186. How does Nance's translation fit with Tib. che ge źig gi 'bras bu 'brel pa?

${ }^{67}$ On kālāpadeśa and its contrary the mahāpadeśa, see Eltschinger 2014: 203-207.

${ }^{68}$ Previous work on Vasubandhu's understudied VY includes Cabezón 1992, Skilling 2000, Horiuchi 2007 and 2009 , and Eltschinger forthc.

${ }^{69}$ VY 6,5-7,4 (P si 33b4-34a1, “2.1. The five means of interpretation”): ji ltar mdo sde rnam par bśad par bya źe na / rnam pa lna dag gis te /

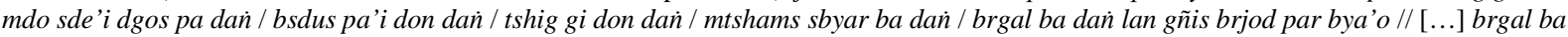

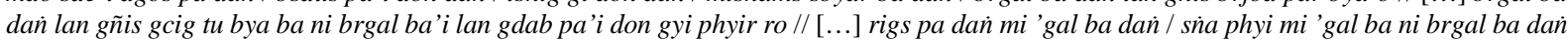
lan las yin pas na [...] //. Translation Nance 2012: 6-7 (brackets mine). The Sanskrit words in brackets are borrowed from Haribhadra's AAA (15,24-26), which cites the VY’s initial verse (VY 6,9-12 [P si 33b5-6], quoted in Skilling 2000: 318): prayojanam sapiṇ̣̂artham padārthah sānusandhikah / sacodyaparihāraś ca vācyah sūtrārthavādibhih // iti pañcabhir ākāraih sūtram vyākhyātavyam iti vyākhyāyuktau nirṇītam /. "It is stated in the Vyākhyāyukti that a sütra must be commented upon via five aspects: 'Those who expound the meaning of a sütra should state [its] purpose together with the summary meaning, the meaning of the phrases together with the connections and the objections and responses.” To be compared with ASBh 142,11-12, with abhiprāya for piṇ̂̄ārtha (Nance 2012: 154).
} 
“connections"; (2) Vasubandhu also regards suspicion of internal inconsistencies and contradictions with reason as what motivates responses to objections, the final element of a scriptural commentary.

3.2.2.1. Let us consider two examples of internal inconsistencies, both of which pertain to important aspects of Buddhist dogmatics: the nature of the mind and (the retribution of) action. Here is the first objection, concerning the nature of the mind: "Among these[, let us now turn to] objections [pointing] to internal contradictions. For example, somewhere [the Blessed One] speaks as follows: 'What is called the mind, what is called the internal organ, and what is called cognition, inasmuch as it perishes every night and day and perishes at every moment, every second, every instant, appears [as] another in many ways and in many respects when it appears, and disappears [as] another [in many ways and in many respects when it disappears].' But somewhere [else, the Blessed One] speaks as follows: 'What is called the mind, what is called the internal organ, and what is called cognition, having been fortified over a long time ( $*$ dìrgharātram, BHSD, SWTTF) by faith, having been fortified by morality, generosity and insight, goes upwards to [its] future state (*samparāya?), goes to distinction [and] reaches heaven (*svargopaga? SWTTF).' How can a momentary (*kșanika) mind [be said to] go upwards in a future time?”70 These two logia of the Blessed One give every appearance of contradicting each other: whereas the Markatasutra emphasizes the mind's momentariness, the second locus, by claiming the mind's perfectibility and gradual improvement, involves its enduring nature. To this, Vasubandhu suggests the following response: "When [the Blessed One] says that the mind is momentary and that it goes upwards, he speaks intending (*abhipretya?) its continuum(/series) (*tatsantāna?); therefore, there is no [internal] contradiction, as [there is a contradiction between] the shadow and the rise of the (sun)light." 71

3.2.2.2. Our second example of an internal contradiction pertains to the utterly difficult question of the agent of actions and the experiencer of their (mainly post-mortem) retribution. Here is the objection: "In the same way, [the Blessed One] says somewhere 'In this world, human beings perform both meritorious actions (*punya?) and sinful actions (*pappa?). Having appropriated and carried them away, [these good and bad actions] cause [them] to transmigrate?'’ But somewhere [else, the Blessed One] says: 'Action exists, [its] maturation (vipāka) exists, too, but an agent (käraka) does not exist (nopalabhyate)."'72 Does an agent of actions exist or not? Is (s)he who acts the same as (s)he who experiences the karmic results of actions? According to Vasubandhu and a majority of the Buddhists, there is neither an agent nor an experiencer, but just a beginningless series of purely momentary (physical and) psychological events whose properties and inclinations are a function of the actions it is responsible for. This is the point of Vasubandhu's answer, which, again, resorts to the hermeneutic principle of the Buddha's intention: "Somewhere, [the Blessed One] says: 'In this world, human beings perform both meritorious actions and sinful actions[, etc.],' and somewhere [else], he says: 'An agent does not exist[, etc.].' There is no [internal] contradiction in this case either, because [the Blessed One] had different things in mind [while delivering these teachings]. To explain, it is in the series of the [five] constituents (*skandhasantāna?) [here metaphorically]

\footnotetext{
${ }^{70}$ VY 169,21-170,9 (P si 101a5-b2, "pūrvāparaviruddha(1)”): de la sña phyi 'gal bar brgal ba ni dper na kha cig las 'di skad du sems śes bya ba'am yid ces bya ba'am rnam par śes pa źes bya ba 'byun் ba gan் yin pa de ni mtshan mo dañ ñi mo de dan் de dag 'das śin skag cig dan் than

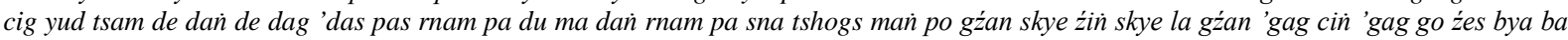
gsuñs pa dan் / kha cig las yan் 'di skad du sems śes bya ba'am yid ces bya ba'am rnam par śes pa źes bya ba 'byun் ba gañ yin pa de ni yun rin் po nas dad pas yon்s su bsgos / tshul khrims dan் gton் ba dan் śes rab kyis yon்s su bsgos pas tshe rabs phyi ma la gon du 'gro źin khyad par du 'gro ba dan் mtho ris su ñe bar 'gro ba yin no źes gsuñs pa la ji ltar na sems skad cig pa tshe phyi ma la gon் du 'gro bar 'gyur /. In the first passage, Vasubandhu is quoting from the Markațasutra, of which we fortunately have the Sanskrit (see Tripathi 1962: 115-120, Traité III.11651167, and Chung N.D.: 102 for further references): yat punar idam ucyate cittam iti vā mana iti vā vijñānam iti vā tat teșām teșām rātridivasānām atyayāt kṣanalavamuhūrtānām atyayāt pravartate bahunānāprakāram anyad evotpadyamānam utpadyate 'nyad eva nirudhyamānam nirudhyate /. “Au contraire ce qui est appelé 'pensée', 'esprit' ou 'connaissance', au fil des nuits et des jours, au cours des instants, des moments et des heures, se présente sous des aspects multiples et divers: quand elle naît c'est [déjà] une autre qui naît, quand elle est détruite, c’est une autre qui est détruite.” Translation Traité III.1166-1167. See also SN II.95 (Bodhi 2000: 595). In the second passage, Vasubandhu quotes from a passage very close to SN V.370, ll. 5-7: yañca khvassa cittam dīgharattam saddhāparibhāvitam sīlasutacāgapañ̃āparibhāvitam tam uddhagāmi hoti visesagāmi /. "But his mind, which has been fortified over a long time by faith, virtue, learning, generosity, and wisdom - that goes upwards, goes to distinction.” Translation Bodhi 2000: 1808. Closer parallels could not be identified.

${ }^{71}$ VY 191,20-22 (P si 109b7-8, "parihāra(6): pūrvāparaviruddha(1)"): sems ni skad cig ma źes bya ba yin la / gon் du 'gro ba yañ yin no źes

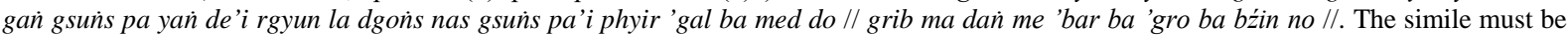
based on a text similar to MN II.235: seyyathāpi bhikkhave yam chāyā jahati tam àtapo pharati / yam àtapo jahati tam chāyā pharati / evam eva kho bhikkhave pavivekāya pītiyā nirodhā uppajjati domanassam domanasassa nirodhā uppajjati pavivekā pīti /. "Just as the sunlight pervades the area that the shadow leaves, and the shadow pervades the area that the sunlight leaves, so too, with the cessation of the rapture of seclusion, grief arises, and with the cessation of grief, the rapture of seclusion arises." Translation Ñānamoli/Bodhi 2001: 844.

${ }^{72}$ VY 170,17-27 (P si 101b3-5, "pūrvāparaviruddha(3)"): de bźin du kha cig las mi rnams kyis ni ’di na bsod nams dan // sdig pa gañ yin gñis

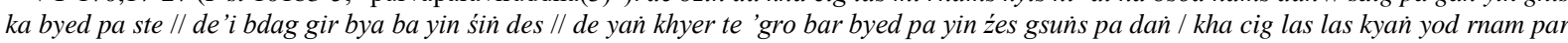
smin pa yañ yod la byed pa po ni mi dmigs so źes gsuns pa [...]//. The first locus (pädas 1-3 of the stanza) is somehow reminiscent of Uv 9.8ab: yat karoti narah karma kalyānam atha pāpakam / (tasya tasyaiva dāyādo na hi karma pranaśyati //). As for the second, which belongs to the Paramārthaśünyatāsūtra, it is frequently quoted in the framework of the controversy over the pudgala ("person"). See, e.g., AKBh 129,9-11 (quoted Lee 2001: 170, n. 1215): asti karmāsti vipākah kārakas tu nopalabhyate /. A slightly longer passage is quoted in MSABh 158,20-22 (for a discussion and further references, see Eltschinger 2010b: 322-323), BCAP 340,22-24 and AKBh 468,23-24 (see also Kośa V.59, n. 3, and below, n. 73).
} 
referred to as 'human being' that the cause of the two [types of actions] is to be found, and it is just in this [series] that the results of the two arise. Thus with this in mind, [the Blessed One] has said: 'In this world, human beings perform both meritorious actions and sinful actions. Having appropriated and carried them away, [these good and bad actions] cause [them] to transmigrate?'. [But when] he said, 'An agent does not exist,' what he had in mind

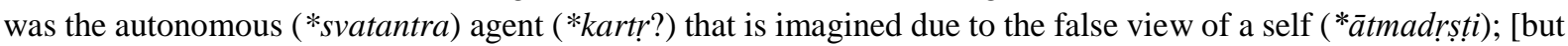
he did] not [speak in this way] on account of the characteristics of the causal complex. For he has specified: '[agent] who would abandon those constituents [at the end of the present life] and take up new constituents [at the beginning of the next]. ${ }^{73}$ Therefore, since he had different things in mind, there is no internal contradiction [between these various statements]." 74

3.2.3.1. As mentioned above, Vasubandhu's view on contradiction with reason(ing) operates with a notion of reason(ing) that is not the same as the VivSg's. The latter's four types of reason(ing) designed what can be regarded as an intrabuddhistic and essentially exegetical/soteriological concept of reason. Recall, however, that the third type of reason(ing), i.e., "reason(ing) proving by means of arguments” (upapattisädhanayukti), consisted in a monk or a bodhisattva providing justification for a certain teaching by resorting to three means of valid cognition, viz. perception, inference, and trustworthy scripture. Vasubandhu's concept of reason(ing) can be seen as a generalization of the upapattisädhanayukti and the role played in it by the means of valid cognition. Accordingly, contradictions with reason(ing) can be defined as inconsistencies with either perception, inference, or authoritative scripture: "In brief, here we call 'reason(ing)' (*nyāya, *yukti) the three means of valid cognition, i.e., perception, inference, and trustworthy scripture. [Any] objection [pointing out] contradictions with whatever [is derived] from these [means of valid cognition] must be known as an objection [pointing out] a contradiction with reason(ing)." 75 Here again, let us briefly review two examples of objections based on contradiction with individual pramānas. ${ }^{76}$

3.2.3.2. According to Vasubandhu, the doctrine according to which everything — past, present, future-exists (the Sarvāstivāda monastic order is named after this controversial doctrine: "those who claim that everything exists") provides a characteristic example of a contradiction with perception —and even more than that: "[Consider,] for example, [the following statement:] 'O monks, past corporeality exists; future corporeality exists. What[ever] has passed away, is destroyed, has ceased to exist, has disappeared and has undergone transformation, [all] this exists.' [This statement] contradicts perception, because it is [empirically] perceptible that past and future [things] simply do not exist, just as the hair of a tortoise (*kūrmaroman?) [does not exist]. Moreover, saying [of something] that it is past and that it exists is an internal contradiction, for if it exists, how [can it be] past? And the same [applies to] the future. In this case, there is a contradiction with what is said [by the Blessed One] in another sütra [i.e.,] 'The eye, when it arises, does not come from anywhere, [and] when it ceases to exist, it does not go anywhere [to be] stored. O monks, the eye comes into existence after not existing and disappears after having come into existence." "77 Vasubandhu's critique has a close parallel in the same author's AKBh (299,1-18; see Kośa V.5860), where the same texts are quoted. The Sarvāstivādin takes the statement that past and future actions exist at its face value. Vasubandhu (speaking here as a Sautrāntika) first provides a semantic analysis of these expressions,

\footnotetext{
${ }^{73}$ Cf. AKBh 468,23-24 (quoted Lee 2001: 193, n. 1396; quotation from the Paramārthaśūnyatāsūtra): (asti karmāsti vipākah kārakas tu nopalabhyate) ya imāṃś ca skandhān nikșipaty anyāmés ca skandhān pratisandadhāty (anyatra dharmasañketāt).

${ }^{74}$ VY 193,4-24 (P si 110b1-6, "parihāra(8): pūrvāparaviruddha(3)": kha cig las mi rnams kyis ni 'di na bsod nams dan் // sdig pa gañ yin gñis

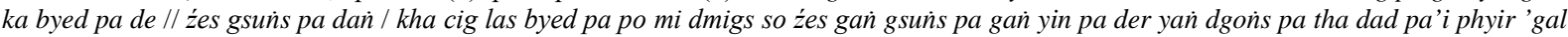
ba med de / 'di ltar phuñ po'i rgyud gañ la mi rnams śes bya ba de la de gñis kyi rgyu yod cin de kho na la de gñis kyan் 'bras bu 'byuñ bas 'di

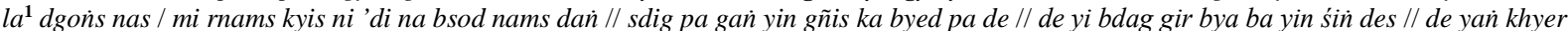
te 'gro bar byed pa yin źes gsuñs pa yin no // bdag tu lta bas kun tu brtags pa'i byed pa po ran் dban் yod pa la dgon்s nas ni byed pa po mi dmigs so źes gsuñs pa yin gyi rgyu tshogs pa'i mtshan ñid las ni ma yin te / 'di ltar gañ źig phun po 'di dag 'dor śin phuñ po gźan dag tu mtshams sbyor bar byed pa'i źes khyad par du mdzad pa yin no // de bas na dgoñs pa tha dad pa'i phyir sina phyi 'gal ba med do //. 'la em. : las Ed.

${ }^{75}$ VY 173,16-17 and 19-20 (P si 102b6-7, “nyāyaviruddha(1)," in fine, and "nyāyaviruddha(2): pratyakșavirodha,” in limine): mdor na rigs pa

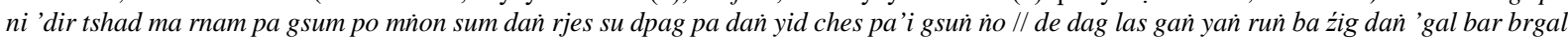
ba yaì rigs pa dà் 'gal bar brgal ba yin par rig par bya'o //.

${ }^{76}$ Due to limitations of space made it impossible to quote Vasubandhu's responses to these objections, which are significantly longer than his answers to the objections pointing to internal inconsistencies.

${ }^{77}$ VY 173,20-174,13 (P si 102b7-103a3, "nyāyaviruddha(2): pratyakșavirodha”): dper na - dge slon dag gzugs 'das pa yod do // gzugs ma

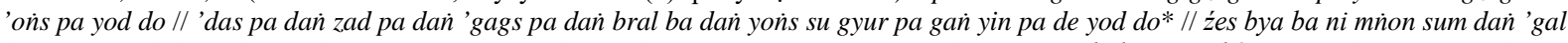
ba yin no // 'di ltar 'das pa dan் ma 'oṅs pa ni med pa ñid yin par minon sum yin te / dper na rus sbal gyi spu bźin no // 'das pa'an் yin la yod pa'an் yin źes bya ba 'di sña phyi 'gal ba yan் yin te / gal te yod na ji ltar 'das pa yin / ma 'on்s pa yan் de dan் 'dra'o // mdo sde gźan las - mig

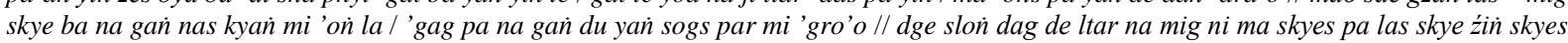
nas kyan் 'jig go** // źes gsuñs pas de dan் 'dir 'gal ba yin no //. *Cf. AKBh 299,6 (quoted Lee 2001: 173, n. 1238; quotation from the Paramārthaśūnyatāsūtra): asty atītam asty anāgatam /. Cf. AKBh 299,9-10 (quoted Lee 2001: 173, n. 1238): yat karmābhyatītam kṣinnam niruddham vigatam viparinatam tad asti /. According to Vasubandhu, the Buddha said this to the "Lagudaśikhīyaka parivrājakas" (see Kośa V.59, n. 2, and AKVy 473,14-19). **Cf. AKBh 299,12-14 (quoted in Lee 2001: 174, n. 1241): cakṣur utpadyamānam na kutaścid āgacchati nirudhyamānam na kvacit sannicayam gacchati / iti hi bhikșavaś cakșur abhūtvā bhavati bhūtvā ca prativigacchati /. The same passage is quoted in BCAP 408,29-31 on BCA 9.142.
} 
arguing that "we, too, say that the past and the future exist, but [in our opinion,] the past is what existed before, [and] the future, what will exist provided [its] cause exists; it is in this sense that we say that they exist, but [certainly] not [in the sense that they would exist] substantially[, as the present exists]." ${ }^{\text {78 }}$ He then suggests that the Sarvāstivāda interpretation of the logion entails an internal contradiction, "for otherwise [i.e., on the Sarvāstivāda interpretation], if [the past] existed of its own, it would not be established as past. ${ }^{79}{ }^{780}$ Finally, Vasubandhu quotes the same excerpt from the Paramārthaśūnyatāsūtra to show that his Sarvāstivādin opponent contradicts authoritative scripture.

3.2.3.3. Our second example presents us with a case of alleged contradiction with authoritative scripture (aggamavirodha), the "mainstream" Buddhists' contention that the Great Vehicle is a forgery (i.e., not the word of the Buddha) because it contradicts the basic teachings of the Buddha. This case is of a particular importance inasmuch as it triggers one of the quantitatively and qualitatively most prominent aspects of the VY, i.e., its apology on behalf of the Great Vehicle, ${ }^{81}$ and inasmuch as it reflects what likely was an important concern of early $1^{\text {st }}$ millenium Indian Buddhist communities. As we can see, the objections (at least theoretically) raised in the framework of commentaries were not limited to sophisticated dogmatic or philosophical issues, but could pertain equally well to important challenges of a socio-historical nature. Here is this objection: "For example, claiming that the Vaipulya [section of the twelvefold word of the Buddha] ${ }^{82}$ is the Great Vehicle is in contradiction with scripture. Some say that the Vaipulya [section simply] consists of extensive sūtra works, but not of the Great Vehicle. - Why? - [Because] it is not the word of the Buddha! - [But] in which way is it not the word of the Buddha? - Because it contradicts [it]! It contradicts the word of the Buddha [as it is] acknowledged in all orders ( ${ }^{*}$ nikāya). For in the [Great Vehicle] are found [claims to the effect] that all factors are selfless, non-arisen [and] non-destroyed, that all factors are originally peaceful [and] in complete cessation by nature; in the same way, one finds [statements such as] 'Corporeality is unreal, O Subhūti, and [everything] up to awakening [itself] is unreal, O Subhūti!' But in the word of the Buddha [as it is] acknowledged in all orders, the Blessed One [is seen to say] 'What is ignorance? - Not to know the past and the [future?]'; he teaches the nature of all factors from birth to old age and death, [saying:] 'Because that exists, this exists,' 'Because that arises, this arises,' 'Visual cognition arises in dependence on eye and corporeality,' [And further:] 'All conditioned things have passed away, are destroyed, have ceased to exist, have disappeared, have undergone transformation.' [And further:] 'Alas, [all] conditioned things are impermanent; they have the property of perishing upon being born; [and] since they are perishing after being born, they are tranquillity and bliss.' [And further:] 'O monks, [all] conditioned things are painful; cessation is peaceful.' [And further:] 'Due to the arising of [its] cause, suffering arises; due to the cessation of [its] cause, suffering ceases. By possessing the causes [responsible for this], one goes to good [rebirth] destinations ( ${ }^{*}$ sugati); by possessing the causes [responsible for this, to] bad [rebirth] destinations; by possessing the causes [responsible for this, one obtains] cessation; all this arises due to possessing the [necessary] causes.' [And further:] 'Corporeality is impermanent, painful [and] changing.' [And further:] 'Those [things] that are accepted to exist by learned [people] in the world, I also say that they exist.' With such statements, [the Blessed One] teaches birth, etc. Therefore, because it contradicts the word of the Buddha [as it is generally] acknowledged, the Great Vehicle is not the word of the Buddha, and thus, claiming that the Vaipulya [section of the twelvefold word of the Buddha] is the Great Vehicle, is contradictory with scripture." ${ }^{83}$

\footnotetext{
${ }^{78}$ AKBh 299,1-3: vayam api brūmo 'sty atītānāgatam iti / atītam tu yad bhūtapūrvam / anāgatam yat sati hetau bhavișyati / evam ca kṛtvā 'stīty ucyate na tu punar dravyatah /. See Kośa V.58.

${ }^{79}$ Yaśomitra (AKVy 473,29-30) glosses svena bhāvena, “of its own,” as pratyutpannalaksanena, "with the character(istic) of the present,” and atitam (iti) na sidhyet as pratyutpannam eva sidhyed ity abhiprāyah, "it would simply be established as present-such is [Vasubandhu's] intention."

${ }^{80}$ AKBh 299,13: anyathā hi svena bhāvena vidyamānam atītam na sidhyet /.

81 This apology is the subject matter of Chapter 4 of the work. On this aspect of the VY as well as for other sources, see, e.g., Cabezón 1992, Skilling 2000: 323-324, Horiuchi 2007 and 2009, and Eltschinger forthc.

${ }^{82}$ On the Vaipulya section of the $d v \bar{a}$ daśängapravacana, see above, n. 58.

${ }^{83}$ VY 175,22-177,18 (P si 103b2-104a4, "nyāyaviruddha(7): āgamavirodha[= Mahāyāna is not Buddhavacana]): de bźin du - śin tu rgyas pa'i sde ni theg pa chen po yin no źes gà̉ bśad pa yan் lun் dàn 'gal ba yin te / kha cig na re mdo sde’i le'u gran்s rgyas pa rnams ni śin tu rgyas pa'i sde yin gyi theg pa chen po ni ma yin no źes zer te / ci'i phyir źe na / de ni sañs rgyas kyi gsuñ ma yin no // ji ltar sañs rgyas kyi gsuñ ma yin źe na / 'gal ba'i phyir te / de ni sde pa thams cad la grags pa'i sañs rgyas kyi gsun் dan் 'gal ba yin no // 'di ltar de las ni -chos thams cad ni rañ bźin med pa / ma skyes pa ma 'gags pa / chos thams cad ni gzod ma nas źi ba / rañ bźin gyis yoñs su mya nan las 'das pa źes bya ba

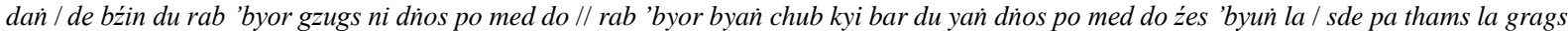

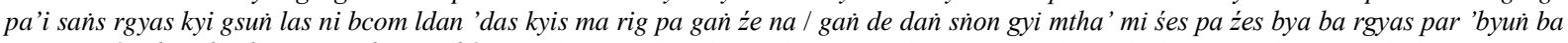
nas / rga śi'i bar du chos rnams kyi rañ bźin yan் bstan / 'di yod pas 'di 'byun் / 'di skyes pa'i phyir 'di skye / mig dañ gzugs la brten nas mig gi rnam par śes pa skye / 'du byed 'di dag thams cad ni 'das zad pa 'gags pa bral ba yon்s su gyur pa'o // kye ma 'du byed rnams mi rtag // skye źin 'jig pa'i chos can yin // skyes nas 'jig par 'gyur bas na // de dag ñe bar źi ba bde // dge sloñ dag 'di lta ste / 'du byed rnams ni sdug bsñal ba'o // mya ñan las 'das pa ni źi ba'o źes bya ba dan் / rgyu kun 'byun் ba las sdug bsinal kun 'byun் ba yin la / rgyu 'gags pa las sdug
} 
3.3. These four cases are far from exhausting the examples of internal and "external" contradictions adduced by Vasubandhu in the VY, but it should be clear by now that pointing to contradictions of either kind, basing objections upon them and answering these form an essential part of Indian Buddhist commentaries as theorized by Vasubandhu and others. Far from being limited to minor philological issues or superficial misunderstandings, these objections pertain to the most important aspects of Buddhist doctrine. It remains to be seen whether those who wrote scriptural commentaries with Vasubandhu's recommendations in mind complied with this modelwhich seems to have been at least partly the case in Kamalaśila's exegetical practice. ${ }^{84}$

Before concluding, let it be briefly mentioned that these two types of contradictions played a significant role in the development and the self-understanding of Buddhist epistemology, a tradition in which, as its name suggests, the means of valid cognition played a key role. Two important aspects of this tradition's treatment of the pramannas are that it limits their number to perception and inference (thus excluding scripture from reliable souces of knowledge), and that it sharply distinguishes the empirical (drsțta) from the transempirical realm (adrssta, [atyanta]parokșa, atīndriya, etc.), the first being accessible to ordinary human cognition (viz., the two pramānas) while the latter is the object of scriptural authority (ägama[prāmannya]). Buddhist epistemology is of an essentially apologetic character. In other words, its principal task is to critically assess (and, needless to say, to reject) the truth claims of other systems and to defend Buddhism against its opponents. There is at least one important passage in Dharmakīti's works demonstrating that yuktivirodha and pürvāparavirodha played a decisive role in this apologetic endeavor, but severed from their originally exegetical context. Whereas, in the exegetical handbooks considered above, yuktivirodha and pürvāparavirodha were two types of contradiction, each is assigned a definite epistemological function in Dharmakīti's system. Assessing the reliability of a given treatise or scripture-what these and earlier authors call a parīkșa or "critical examination"-proceeds in two ways: first, its empirical statements should be checked against perception and inference; second, since those of its statements that pertain to the transempirical realm can be neither verified nor falsified, its internal consistency while dealing with supersensible things at least should be checked, and this is tantamount to searching for pürvāparavirodha. Here is this all-important passage: “The [treatise]'s reliability consists in the fact that neither perception nor the two kinds of inferences [i.e., inference based on the force of real things and scripturally based inference,] invalidates the empirical or transempirical things [that are] their [respective] objects. [A treatise's] not being invalidated by perception consists [first] in the fact that the things it holds to be perceptible are indeed such [i.e., perceptible], for example [the five skandhas, i.e., colours] such as blue, [affective sensations such as] pleasure and pain, [ideation consisting in one's] grasping the characteristics [of things, conditioning factors] such as desire, and cognitions[, which are all perceived by sensory perception and self-awareness. Second, a treatise's not being invalidated by perception consists] in the fact that the [things] it does not hold to be such [i.e., perceptible,] are [indeed] imperceptible, for example [pseudo-constituents] such as pleasure, which [the Sānkhya erroneously takes to] combine in the form of sounds, etc., and [categories] such as substances, motions, universals and connections[, which the Vaiśeșika erroneously takes to be perceptible]. Similarly, [a treatise's not being invalidated by inference] consists [first] in the fact that the [things] it holds to be the objects of an inference that does not depend on scripture are really such [i.e., inferable], as the four nobles' truths, [and second] in the fact that the [things it holds to be] non-inferable are really such [i.e., noninferable], like the self, [God,] etc. [And this type of invalidation is] also [relevant] concerning an inference that depends on scripture[, which consists in identifying internal contradictions within a treatise]: for example, once it is admitted that demerit has the nature of [defilements] such as desire and the [corporeal and verbal acts] that originate from them, one does not prescribe [things] such as ablutions and fire oblation in order to remove it [i.e., demerit, because they cannot annihilate its cause].”85

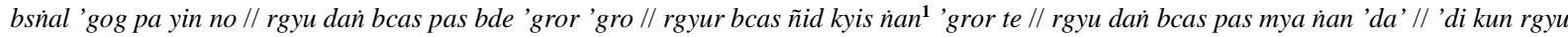
dañ bcas las 'byù // źes bya ba dan் / de bźin du gzugs ni mi rtag pa sdug bsinal ba 'gyur ba'i chos can no źes bya ba dañ / 'jig rten na mkhas pa rnams kyis yod par 'dod pa gan் yin pa de ni ṅa yan் yod par smra'o źes bya ba de lta bu la sogs pa 'byun bas skye ba la sogs pa yan் bstan

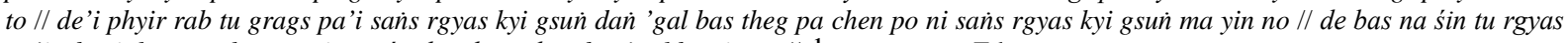

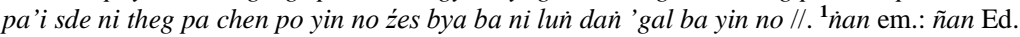

${ }^{84}$ See Schoening 1992: 224 and 1995: II.15-47.

${ }^{85}$ PV 1.215 and PVSV 108,20-109,3: pratyakșenānumānena dvividhenāpy abādhanam / drșțādrșțārthayor asyāvisamvādas tadarthayoh // pratyakṣeṇābādhanam pratyakṣābhimatānām arthānām tathābhāvah / yathā nīlādisukhaduḥkhanimittopalakṣanarāgādibuddhīnām / atathābhimatānām cāpratyakșatā / yathā śabdādirūpasanniveśinām sukhādīnām dravyakarmasāmānyasamyogādīnām ca / tathānāgamāpekșānumānavișayābhimatānām tathābhāvah / yathā caturṇām āryasatyānām / ananumeyānām tathābhāvah / yathātmādīnām / āgamāpekșānumāne 'pi yathā rāgādirūpam tatprabhavam cādharmam abhyupagamya tatprahānāya snānāgnihotrāder anupadeśa h /. On this passage, see Eltschinger 2007: 105-109 and 221-223 (especially nn. 23-27).
} 


\section{Conclusion}

Both in the Latin Middle Ages and in Indian Buddhist scholasticism, a significant part of doctrinal elaboration and philosophical thinking was embedded in or closely connected to scriptural commentary and emancipated itself from it in the form of the quaestio disputata and the disputatio on the one hand, of a type of parìkșa on the other. In both contexts, contradictions between conflicting authorities, internal contradictions and other kinds of inconsistencies motivated objections that were critically addressed at the end of a commentarial sequence. In both contexts, the main expressions of "mature" philosophical activity bear strong formal and structural reminiscences of this origin. This is certainly not to say that philosophy arose from exegesis, of course, for even in the Buddhist context, at least a form of philosophy preexisted this type of commentary. But forms first developed in the framework of commentarial activity shaped and strengthened the type of philosophical expression that was to dominate the two intellectual cultures at their acme $\left(12^{\text {th }}-14^{\text {th }} \mathrm{c}\right.$. and $6^{\text {th }}-12^{\text {th }}$, respectively).

\section{References}

AAA—Unrai Wogihara: Abhisamayālañkārālokā Prajñāpāramitāvyākhhyā, The Work of Haribhadra. Vol. I. Tokyo 1932: The Toyo Bunko.

AK(Bh)—P. Pradhan: Abhidharmakośabhāssyam of Vasubandhu. Patna 1975: K.P. Jayaswal Research Institute (Tibetan Sanskrit Works Series 8).

AKVy—U. Wogihara: Sphuțarthā Abhidharmakośavyākhyā, The Work of Yaśomitra. Tokyo 1936: Sankibo Buddhist Book Store (The Publishing Association of the Abhidharmakośavyākhyā).

ASBh—N. Tatia: Abhidharmasamuccayabhāșyam. Patna 1976: K.P. Jayaswal Research Institute (Tibetan Sanskrit Works Series 17).

BAzÁN, B.C. 1985. “Les questions disputées, principalement dans les facultés de Théologie.” In B.C. Bazán, G. Fransen, G. Wippel, D. Jacquart, eds.: Les questions disputées et les questions quodlibétiques dans les Facultés de théologie, de droit et de médecine. Pp. 15-149. Turnhout: Brepols.

BCA(P)—Swami Dwarika Das Shastri: Bodhicaryāvatāra of Ārya Śāntideva with the Commentary Pañjikā of Shri Prajñākaramati and Hindi Translation. Varanasi 1988: Bauddha Bharati (Bauddha Bharati Series 21).

BHSD—F. Edgerton: Buddhist Hybrid Sanskrit Grammar and Dictionary. Vol. II: Dictionary. New Haven 1953: Yale University Press.

Biardeau, Madeleine. 1969. “Philosophie de l’Inde.” In Brice Parain, éd.: Histoire de la philosophie. Vol. I: Orient, Antiquité, Moyen âge. Pp. 82-247. Paris: Éditions Gallimard.

Blanche, F.A. 1925. "Le vocabulaire de l'argumentation et la structure de l'article dans les ouvrages de S. Thomas.” Revue des sciences philosophiques et théologiques 14 : 167-187.

BoDHI, Bhikkhu. 2000. The Connected Discourses of the Buddha. A Translation of the Samyutta Nikāya. Boston: Wisdom Publications.

CABEzón, José Ignacio. 1992. "Vasubandhu's Vyākhyāyukti on the Authenticity of the Mahāyāna Sūtras." In J. Timm, ed.: Traditional Hermeneutics in South Asia. Pp. 221-243. Albany: State University of New York Press.

—. 1994. "Scholasticism.” In José Ignacio Cabezón: Buddhism and Language. A Study of Indo-Tibetan Scholasticism. Pp. 1126. Albany: State University of New York Press.

—. 1998. Ed.: Scholasticism. Cross-Cultural and Comparative Perspectives. Albany: State University of New York Press.

CHENET, François. 1998. “Le commentaire en Inde.” In Jean-François Mattei, ed.: Le Discours philosophique (Encyclopédie philosophique universelle, IV). Pp. 1656-1664. Paris: Presses Universitaires de France.

Chenu, M.-D. 1959. St Thomas d'Aquin et la théologie. Paris: Éditions du Seuil.

—. $1993\left(1954^{1}\right)$. Introduction à l'étude de Saint Thomas d’Aquin. Montréal and Paris: Institut d'études médiévales and Librairie philosophique Jean Vrin.

Chung, Jin-il. N.D. A Survey of the Sanskrit Fragments Corresponding to the Chinese Samyuktāgama. No place, no date, no editor mentioned.

D—Jikido Takasaki, Zuiho Yamaguchi and Noriaki Hakamaya: sDe dge Tibetan Tripitaka bsTan 'gyur preserved at the Faculty of Letters, University of Tokyo. Tokyo 1977-1981.

DE RIJK, Lambert Marie. 1985. La philosophie au moyen âge. Translated from Dutch (Middeleeuwe wijsbegeerte. Traditie en vernieuwing, Assen, 1981) by P. Swiggers. Leiden 1985: E.J. Brill. 
Deleanu, Florin. 2006. The Chapter on the Mundane Path (Laukikamārga) in the Srāvakabhūmi. A Trilingual Edition (Sanskrit, Tibetan, Chinese), Annotated Translation, and Introductory Study. 2 vols. Tokyo: The International Institute for Buddhist Studies.

DelHEY, Martin. 2013. “The Yogācārabhūmi Corpus. Sources, Editions, Translations, and Reference Works.” In Ulrich Timme Kragh, ed.: The Foundation for Yoga Practitioners. The Buddhist Yogācārabhūmi Treatise and Its Adaptation in India, East Asia, and Tibet. Pp. 498-561. Cambridge, Mass.: Department of South Asian Studies, Harvard University.

Eltschinger, Vincent. 2007. Penser l'autorité des Écritures. La polémique de Dharmakīti contre la notion brahmanique orthodoxe d'un Veda sans auteur. Autour de Pramānavārttika I.213-268 et Svavrtti. Vienna: Austrian Academy of Sciences Press.

—. 2010a. "Studies in Dharmakīti’s Religious Philosophy: 4. The Cintā-maȳ̄ Prajñā." In Piotr Balcerowicz, ed.: Logic and Belief in Indian Philosophy. Pp. 553-591. Delhi 2010: Motilal Banarsidass.

—. 2010b. "On a Hitherto Neglected Text against Buddhist Personalism: Mahāyānasūtrālañkāra 18.92-103 and its Bhāṣa." Asiatische Studien/Études Asiatiques 64/2 : 291-340.

-. 2014. Buddhist Epistemology as Apologetics. Studies on the History, Self-understanding and Dogmatic Foundations of Late Indian Buddhist Philosophy. Vienna: Austrian Academy of Sciences Press.

—. 2017. "Qu'attendre d’une comparaison des scolastiques? Bouddhisme indien et Occident médiéval.” Socio-anthropologie 36 (=Frédéric Fruteau de Laclos and Christophe Grellard, eds., Manières de croire): 123-142.

—. forthc. "Mahāyāna Apologetics between History and Prophecy." To be published in Hōrin.

Glorieux, Palémon. 1968. "L’enseignement au moyen âge. Techniques et méthodes en usage à la Faculté de Théologie de Paris, au XIII siècle.” Archives d'Histoire Doctrinale et Littéraire du Moyen Âge 43 : 65-186.

HoriUCHI, Toshio. 2007. “On the 'Lost’ (*Antarhita) Sūtras in the Vyākhyāyukti.” Journal of Indian and Buddhist Studies 55/3 : 1106(/78)-1111(/83).

—. 2009. Vasubandhu's Proof of the Authenticity of the Mahāyāna as Found in the Fourth Chapter of his Vyākhyāyukti. Tokyo: The Sankibo Press. [In Japanese with an English summary, pp. 417-424.]

HuLIN, Michel. 2000. "Le commentaire dans la littérature philosophique de l’Inde ancienne.” In M.-O. Goulet-Cazé, ed.: Le commentaire entre tradition et innovation. Actes du Colloque de l'Institut des Traditions Textuelles (Paris et Villejuif, 22-25 septembre 1999). Pp. 425-434. Paris: Librairie philosophique J. Vrin (Bibliothèque d'histoire de la philosophie, nouvelle série).

IмBACH, Ruedi. 2010. "Expertus sum. Vorläufige Anmerkungen zur Bedeutung des Verbs experiri bei Albert dem Grossen, Siger von Brabant und Thomas von Aquin.” In O. Weijers, I. Costa, A. Oliva, eds.: Les innovations du vocabulaire latin à la fin du moyen âge: autour du Glossaire du latin philosophique. Pp. 61-88. Turnhout 2010: Brepols.

Kenny, Anthony, and Jan PinBorg. 1982. “Medieval Philosophical Literature.” In N. Kretzmann, A. Kenny, J. Pinborg, eds.: Cambridge History of Later Medieval Philosophy. From the Rediscovery of Aristotle to the Disintegration of Scholasticism, 1100-1600. Pp. 11-42. Cambridge: Cambridge University Press.

Kośa —Louis de La Vallée Poussin: L'Abhidharmakośa de Vasubandhu. 6 vols. Paris and Louvain 1923-1931: Paul Geuthner and J.-B. Istas (Mélanges Chinois et Bouddhiques 16).

LAMOTTE, Étienne. 1976. Histoire du bouddhisme indien, des origines à l'ère Śaka. Louvain-la-Neuve: Université de Louvain, Institut Orientaliste.

LEE, Jong Cheol. 2001-See VY.

Masson-Oursel, Paul. 1911. “Objet et méthode de la philosophie comparée.” Revue de Métaphysique et de Morale 19 : 541 548.

—. 1920. “La Scolastique (étude de philosophie comparée).” Revue Philosophique de la France et de l’Étranger 90 : 123-141.

MN II—Robert Chalmers: The Majjhima-Nikāya. Vol. II, part II. London 1898: Pali Text Society.

MSA(Bh)—Sylvain Lévi: Mahāyāna-Sūtrālaṃkāra, Exposé de la doctrine du Grand Véhicule. Tome I : Texte. Paris 1907: Librairie Honoré Champion (Bibliothèque de l’École des Hautes Études, Sciences historiques et philologiques, 159).

NANCE, Richard. 2012. Speaking for Buddhas. Scriptural Commentary in Indian Buddhism. New York: Columbia University Press.

ÑĀṆAmOLI, Bhikkhu, and Bhikkhu BoDHI. 2001. The Middle Length Discourses of the Buddha. A Translation of the Majjhima Nikâya. Boston: Wisdom Publications (Teachings of the Buddha).

NAtTiER, Jan. 2004. “The Twelve Divisions of Scriptures () in the Earliest Chinese Buddhist Translations.” Annual Report of The International Research Institute for Advanced Buddhology at Soka University, for the Academic Year 2003, 7 : 167196.

Oberhammer, Gerhard, Ernst Prets, and Joachim Prandstetter. 1991-2006. Terminologie der frühen philosophischen Scholastik in Indien. 3 vols. Vienna: Austrian Academy of Sciences Press.

P-Daisetz T. Suzuki: The Tibetan Tripitaka, Peking Edition, Kept in the Library of the Otani University, Kyoto. Tokyo/Kyoto 1957: Tibetan Tripitaka Research Institute. 
PANOFSKY, Erwin. 1957. Gothic Architecture and Scholasticism. New York and London: Meridian Books, Thames and Hudson.

Patrologia Latina_Jacques-Paul Migne: Patrologiae cursus completus, series latina. 217 vols. Petit-Montrouge 1844-1855: apud J.-P. Migne editorem.

Pollock, Sheldon. 2015a. “Introduction.” In S. Pollock, B.A. Elman, and Ku-ming Kevin Chang, eds.: World Philology. Pp. 1-24. Cambridge, Mass., and London: Harvard University Press.

Pollock, Sheldon. 2015b. "What was Philology in Sanskrit?” In S. Pollock, B.A. Elman, and Ku-ming Kevin Chang, eds.: World Philology. Pp. 114-136. Cambridge, Mass., and London: Harvard University Press.

PreisendanZ, Karin. 2008. “Text, Commentary, Annotation: Some Reflections on the Philosophical Genre.” Journal of Indian Philosophy 36 : 599-618.

PV 1-See PVSV.

PVSV—Raniero Gnoli: The Pramānavārttika of Dharmakīti. The First Chapter with the Autocommentary. Roma 1960: Istituto Italiano per il Medio ed Estremo Oriente (Serie Orientale Roma 23).

Ratié, Isabelle. 2013. "On Reason and Scripture in the Pratyabhijñā.” In V. Eltschinger and Helmut Krasser, eds.: Scriptural Authority, Reason and Action. Proceedings of a Panel at the $14^{\text {th }}$ World Sanskrit Conference, Kyoto, September 2-5, 2009. Pp. 375-454. Vienna: Austrian Academy of Sciences Press.

Riché, Pierre, and Jacques Verger. 2013 (2006 $)$. Maîtres et élèves au Moyen Âge. Paris: Librairie Arthème Fayard/Pluriel.

SAKUMA, Hidenori S. 1990. Die Áśrayaparivrtti-Theorie in der Yogācārabhūmiḥ. 2 vols. Stuttgart: Franz Steiner Verlag.

Schmithausen, Lambert. 1969. "Zur Literaturgeschichte der älteren Yogācāra-Schule.” In Wolfgang Voigt, ed.: XVII. Deutscher Orientalistentag: Vorträge (= Zeitschrift der Deutschen Morgenländischen Gesellschaft, Supplementa I.3). Pp. 811-823. Wiesbaden: Franz Steiner Verlag.

Schoening, Jeffrey D. 1992. “The Ārya-śālistambasya-țikā: Kamalaśîla’s Commentary on the Śālistamba-sūtra. In Shoren Ihara and Zuiho Yamaguchi, eds.: Tibetan Studies. Proceedings of the $5^{\text {th }}$ Seminar of the International Association of Tibetan Studies, Narita 1989. Pp. 221-235. Narita: Naritasan Shinshoji.

Schoening, Jeffrey D. 1995. The Śălistamba Sūtra and Its Indian Commentaries. 2 vols. Vienna: Arbeitskreis für tibetische und buddhistische Studien Universität Wien.

SCHÖNBERGER, Rolf. 1991. Was ist Scholastik? Hildesheim: Bernward.

SEYFORT RUEGG, David. forthc. "Remarks on Updating, Renewal, Innovation, and Creativity in the History of some Indian and Tibetan Knowledge Systems and Ways of Thought.” To be published in V. Eltschinger, M. Sernesi, and V. Tournier (eds.): Festschrift Cristina Scherrer-Schaub [provisional title].

SKILLING, Peter. 2000. "Vasubandhu and the Vyākhyāyukti Literature." Journal of the International Association of Buddhist Studies 23/2 : 297-350.

SN II—Léon Feer: Samyutta-Nikāya. Part II: Nidāna-vagga. London 1888: Pali Text Society.

SN V_Léon Feer: Samyutta-Nikāya. Part V: Mahā-vagga. London 1898: Pali Text Society.

SolÈre, Jean-Luc. 2002. “Scolastique.” In Claude Gauvard, Alain de Libera and Michel Zink, eds.: Dictionnaire du Moyen Âge. Pp. 1299a-1310b. Paris: Presses Universitaires de France.

SWTTF-Heinz Bechert, dir., et al.: Sanskrit Wörterbuch der buddhistischen Texte aus den Turfan-Funden. Göttingen 1973ff.: Vandenhoeck \& Ruprecht, Akademie der Wissenschaften in Göttingen.

Traité III—Étienne Lamotte: Le Traité de la Grande Vertu de Sagesse de Nāgārjuna (Mahāprajñāpāramitāsāastra). Vol. III. Louvain: Université de Louvain, Institut Orientaliste.

TRIPATHI, Ch. 1962. Fünfundzwanzig Sūtras des Nidānasamyukta (Sanskrittexte aus den Turfanfunden VIII). Berlin: Akademie-Verlag.

TuBB, Gary A., and Emery R. Boose. 2007. Scholastic Sanskrit, A Manual for Students. New York: The American Institute of Buddhist Studies at Columbia University in the City of New York.

Uv-Franz Bernhard: Udānavarga (Sanskrittexte aus den Turfanfunden X). Göttingen 1965: Vandenhoeck \& Ruprecht (Abhandlungen der Akademie der Wissenschaften in Göttingen, philologisch-historische Klasse, Dritte Folge, 54).

VY-Jong Cheol Lee: The Tibetan Text of the Vyākhyāyukti of Vasubandhu, Critically Edited from the Cone, Derge, Narthang and Peking Editions. Tokyo 2001: The Sankibo Press (Bibliotheca Indologica and Buddhologica 8).

WeIJERs, Olga. 1996. Le maniement du savoir. Pratiques intellectuelles à l'époque des premières universités $\left(X I I I^{e}-X I V^{e}\right.$ siècles). Turnhout: Brepols.

—. 2013. In Search of the Truth. A History of Disputation Techniques from Antiquity to Early Modern Times. Turnhout: Brepols.

-. 2015. A Scholar's Paradise. Teaching and Debating in Medieval Paris. Turnhout 2015: Brepols (Studies on the Faculty of Arts, History and Influence, 2).

YoBh-Yogācārabhūmiśāstra, Tibetan version. D no. 4035-4042, tshi, dzi, wi, źi, zi, 'í P. no. 5536-5543, dzi, wi, źi, zi, ’i, yi. 
Yoshimizu, Chizuko. 1996. Die Erkenntnislehre der Prāsañgika-Madhyamaka nach dem Tshig gsal ston thun gyi tshad ma'i rnam bśad des dByan்s bźad pa'i rdo rje. Einleitung, Textanalyse, Übersetzung. Vienna: Arbeitskreis für tibetische und buddhistische Studien Universität Wien. 